\title{
Do Fiscal Deficits Stimulate Economic Growth in Nigeria? A Disaggregated VAR Analysis
}

\author{
Nwaeze, Nnamdi Chinwendu (Ph.D) \\ Department of Economics, Abia State University, Uturu
}

\begin{abstract}
Fiscal deficits which emanates from the unbalancing of the annual budgets are mostly prescribed to developing countries by development apologists, given the acclaimed expansionary effects it has on output and employment. This study investigates the relationship between fiscal deficits and economic growth in Nigeria from 1970 to 2016. The data for the empirical analysis was sourced from secondary sources such as the CBN statistical bulletin. The study used GDP per capita (GDPP) to proxy economic growth whereas Overall Fiscal Deficits (OFDE), fiscal deficit financed by Domestic Borrowing (DBFD), fiscal deficit financed by External Borrowing (EBFD), and Domestic Credit to the Private Sector (DCPS) are used as the endogenous variables. The study employed descriptive statistics, unit root test, co-integration and VAR estimation methods to analyze the data. The results of the variance decomposition reveal that overall fiscal deficits (OFDE) and especially the size of fiscal deficits financed by external borrowing (EBFD) are the main shocks causing the variation in GDP per capita (proxy of economic growth). The study concludes that fiscal deficits have significant positive impact on economic growth. Thus, fiscal deficits especially when financed chiefly by external borrowing are capable of stimulating economic growth in Nigeria. The study recommends that fiscal deficits should be moderated and financed chiefly through external borrowing and possibly bonds as empirical finding suggests that domestic borrowing options are relatively ineffectual in stimulating economic growth in Nigeria.
\end{abstract}

Keywords: Fiscal deficit, economic growth, external borrowing, aggregate demand, interventionist and crowding out.

DOI: $10.7176 / \mathrm{JESD} / 10-11-03$

Publication date:June $30^{\text {th }} 2019$

\section{INTRODUCTION}

Modern development theorists especially the Keynesian and Neo- Keynesian theorists favour the unbalancing of government fiscal budget owing to its acclaimed expansionary effects on economic growth and development. For economic growth and development to be achieved, a country especially the less developed nations who most a times lack adequate savings and capital formation and critical infrastructures; as well as the private sector's lack of the desired capacity to drive growth and industrialization, needs government interventions in the form of expansionary fiscal policy to raise savings and capital formation, improve critical infrastructures and to develop the productive capacity of the economy.

The above noble economic growth and development objectives are chiefly the reasons why countries are prescribed to undertake fiscal deficits. Fiscal deficits arises as a result of fiscal authority's deliberate action of unbalancing the fiscal budgets in the form of budget deficits. Deficit budget therefore is a deliberate fiscal policy of government whereby budgeted expenditures exceeds budgeted revenues in a given time period, usually a year. Given the rise of such deliberate deficits so created, there arises the need to bridge these deficits in terms of the funding. According to Anyanwu (1998) and Udaba (2002) fiscal deficits are conventionally financed by any or combination of the following options: public borrowing (domestic and external), money creation, drawing from accumulated reserve balances, sale of government assets, proceeds from privatization of public enterprises and/or with share of current revenues of government, among others.

Ideally, these aforementioned means of financing fiscal deficits have their respective macroeconomic implications or outcomes. Some of these methods of financing deficit may be counterproductive to the macroeconomic objectives of price stability and economic growth which fiscal deficit originally set out to achieve. For instance, financing deficits through borrowing (both domestic and foreign) could lead to accumulated debt burden of both principal and interest. Also, financing deficits through domestic borrowing according to some scholars could lead to "crowding out" of private investment spending and interest sensitive consumer spending, thereby inhibiting the multiplier effect of the initial public expenditure and by extension, contract economic growth that was primarily targeted. Crowding out effect may arise as a result of continuous government borrowing from the domestic market to finance fiscal deficits. The implication therefore is that government would competing with private investors for available loanable funds. This competitive demand for funds would drive the equilibrium interest rate upward. Given that investment and rate of interest are inversely related, this option of financing deficit would ultimately result in crowding out of private investment which negates the intended economic growth objectives of undertaking fiscal deficits.

The work of John Maynard Keynes in his book titled "The General Theory of Employment, Interest and 
Money in 1936; as well as the aftermath of the "Great Depression" of the early 1930s which ravaged the United States, gave prominence to fiscal policy in particular and Keynes theory in general as a panacea to curbing the problems of unemployment, low output/growth and national income. Keynes believe that unemployment and depression was as a result of deficiency in aggregate demand. Therefore, expansion in government consumption or reduction in taxes can stimulate employment, output and income through the multiplier. He premised his theory on the fact that the economy is inherently unstable and needs to be steadied through vigorous government intervention and/or appropriate policies of government. Deficit financing to the Keynesians is as an important tool to achieve a desired level of aggregate demand consistent with full employment. However, fiscal policy according to the Monetarists are basically interventionists in nature given that they have a shorter lag. Fiscal deficits are most desirable in an economy faced with deficiencies in aggregate demand or an economy experiencing recession or depression as the case may be (Mohanty, 2012).

In the case of Nigeria, however, fiscal deficits dates back to 1961 when the first deficit financing exercise was undertaken and subsequently it became presumably part of the budgetary norms in the country. For instance, from 1970 to 2016 with the exception of these years: 1971, 1973, 1974, 1979, 1995, \& 1996 where overall fiscal surpluses of \#0.171billion, \#0.166billion, \#1.80billion, \#1.16billion, \#1billion, and \#32.05billion respectively were recorded, Nigeria has had 4 decades (40 years) of sustained overall fiscal deficits. Whereas overall fiscal deficits were N0.455billion in 1970, it rose to N2.82billion in 1978, N3.6billion, N35.76billion, N221.05billion, N1.158trillion and N1.577trillion in 1981, 1991, 2001, 2011 and 2015 respectively (CBN, 2015).

The nature of these fiscal deficits in terms of where these expenditures are channeled has been a burning issue in public discourse. There has obviously been an expansion in government expenditures which may have warranted the deficits being sustained over the years. However, the expansion in government expenditures have been skewed chiefly in favour of recurrent expenditures. On the average, over seventy (70) percent of Nigeria's annual budgets have been spent on recurrent expenditures with capital expenditures having less than thirty (30) percent of the total budget government expenditures. For instance, since turn of the $21^{\text {st }}$ century in the year 2000 government recurrent expenditures have outpaced capital expenditures in Nigeria consistently and massively too. While recurrent expenditure was \#460.60billion, \#1.032trillion, \#2.12trillion, \#3.31 trillion \& \#3.83trillion for the years 2000, 2004, 2008, 2011 and 2015 respectively, as against capital expenditures of \#239.45billion, \#351.30billion, \#960.89billion, \#918.55billion \& \#818.37billion for the same years as stated above respectively (CBN, 2015). In terms of total expenditures, the expansion has been astronomical within the periods under review. Whereas total government expenditures in 1981 was \#11.41billion, it increased prodigiously to \#22.02billion, \#92.80billion, \#701.06billion, \#1.82trillion, \#4.99trillion \& N6.03trillion for the years 1987, 1992, 2000, 2005, 2015 and 2016 respectively. The trend continues even with the 2017 Federal government budget appropriation that is yet to be approved 2017 has an estimated total expenditures of N7.45trillion.

According to Obi and Nurudeen (2008) Nigeria's fiscal deficits have been blamed for much of the economic crisis that beset it resulting in over indebtedness in both external and domestic borrowing, public debt crisis, high inflation, poor private investment performance and economic growth. As observed by Onwiodvokit (2005) economic growth in Nigeria has been slowed down over the years due to the deplorable state of some social factors which include poor educational infrastructures, high mortality rate, endemic diseases, growing urban population, and lack of access to sanitation in the urban and rural areas, corruption, weak industrial infrastructure, ethnic conflict/crisis and low per capital income. The solution to this dangerous and unwanted situation lies in accelerated economic growth and development in real terms.

Given the obvious expansion in government expenditures and sustained fiscal deficits, this study shall investigate the long run relationship between fiscal deficits and economic growth, with the aim of establishing empirically if fiscal deficits have actually stimulated and/or achieved the economic growth objective of undertaking them over the years. A disaggregated evaluation of how these deficits are financed vis-a-viz domestic and external borrowing financing, and their magnitude influences in stimulating economic growth or otherwise shall be the major crux and/or departure of this study from previous ones. The study period shall enclose from 1970 to 2016.

\section{LITERATURE REVIEW}

\subsection{Review of Theoretical Literature}

The main objective of fiscal policy is to effect a countercyclical policy so that booms and depressions during the course of business cycles are counterbalanced. By this, therefore, we mean that fiscal policy is fundamentally used in fine-tuning the economy; this is why Keynes (1936), advocated for deficit financing, (an injection into the economy to stimulate aggregate demand) to effect a transition from mass unemployment to near full employment. The theoretical framework of this work therefore, is based on Keynes theory of employment which gave utmost relevance to fiscal policy and government consumption. However, the criticisms of this postulation and the corresponding versions as presented by the Classical and the neoclassical economists as well as the Ricardian equivalence shall also be stated. 
In the Keynesian theory of employment, public spending can contribute positively to stimulating economic growth. An increase in government consumption is likely to lead to an increase in employment, profitability and investment through the multiplier effects on aggregate consumption. As a result government spending augments the aggregate demand, which triggers an increased output depending on expenditure multipliers. To Keynes, the economy is inherently unstable and needs to be steadied through vigorous government intervention and/or appropriate policies of government. Deficit financing to the Keynesians is as an important tool to achieve a desired level of aggregate demand consistent with full employment. The major assumption of this theory is that the economy is working at less than full employment level of national income. Given the existence of output gap in the economy, increase in debt financed government expenditure will bring expansion in output and income. Thus, they argue that an escalation in government spending through the use of borrowed money cause an upward shift on the aggregate demand curve. By implication therefore, deficit financing according to the Keynesian theory can be used to create additional employment when the economy is suffering from a deficiency of effective demand. As an instrument of recovery after recession, deficit financing can be used to mitigate against severe cyclical fluctuations (Dewett, 2009).

Keynesian postulation on the efficacy of fiscal deficit being able to stimulate employment and economic growth is premised on his multiplier concept. If the assumption of the existence of unutilized human and material resources in terms of economic recessions holds therefore, an increase in government spending (or tax reduction) over its revenue will increase both investment and consumption hence leading to expansion of output in multiples of the government expenditure, which Keynes christened the government expenditure multiplier. However, the magnitude of the output expansion is a function of the marginal propensity to consume (MPC) in the economy. Summarily therefore, government spending increases total output more rapidly in an economy with high MPC than country with low MPC.

The above theory however was strongly opposed by the classical and neoclassical schools. The classical school criticism postulate that fiscal deficits incessantly financed by domestic debt crowds out investment and by extension lower the level of economic growth. In sum, they postulate that excessive fiscal deficits lead to poor economic performance. Thus, fiscal deficits financed by public debts are principally counterbalance by the crowding out effect of deficit financing on private sector investment, and this by extension lowers the level of economic growth. The implication of such policy does not stop at the crowding out effect on private investment, also the society will have to bear the burden of increased public debts as a result of debt financed expansion in government expenditure. This overriding objection of Keynes employment theory as well as the efficacy of fiscal deficit in stimulating economic growth by the classical economists was premised on their assumption that the economy always operates at full employment. If an economy is already operating at full employment, any extra expenditure financed by debt or by money creation is bound to create inflationary rise in prices (Anyanwu, 1995); (Dewett, 2009).

On their part, the neo-classical economists collaborated the position of the classical economists that fiscal deficit would have adverse effect on economic growth. Their argument is that fiscal deficit is an obvious weakening of government savings. If government savings are weakened, it will put pressure on rate of interest except if it is fully offset by private savings. Therefore, a decline in national savings will exert pressure on cost of credit (interest rate) which crowds out private investment and a resultant fall in general level of output in the longrun. The neoclassical economists further argued that the manner in which the deficit is financed is capable of influencing the level of consumption and investment and by extension economic growth (Omitogun and Tajudeen, 2007); (Mohanty, 2012).

Furthermore, the contribution of the Ricardian equivalent theory is that of a neutrality effect of fiscal deficit on economic growth. The theory is premised on the assumption that individuals maintain permanent consumption pattern over their life-time. If this assumption holds, it therefore follow that any excess of government expenditure over revenue enjoyed by the public today must be paid in form of tax in the near future. By this, expansionary budget will not have effect on the present individuals' consumption, as they will rather save against the tax burden to be paid in the future. In the case of investment, expansionary budget which infers reduction in government savings may be fully offset by the private savings as such having no effect on cost of credit thereby having an indifferent effect on investment. To the Ricardian equivalent theory summarily, fiscal deficits will neither affect real interest rate to crowd out investment nor stimulates consumption to expand output. Therefore fiscal deficit is a useful stabilization technique to smoothen the impact of revenue shocks or for meeting the requirements of lumpy expenditures (Mohanty, 2012).

\subsection{Review of Empirical Literatures}

From the theoretical reviews, it is clemently obvious therefore that the subject of fiscal deficit and its' effect on the economy has been characterized by a great deal of controversies and counter arguments. These controversies has continued to dominate policy discussions in the developed, developing and the underdeveloped economies.

The work of Mohanty (2012) investigated the impact of fiscal deficit on economic growth in India using 
vector error correction model. His result revealed a significant negative relationship between fiscal deficit and economic growth with evidence of no causality between the two variables. Thus, fiscal deficits contracts economic growth in India. Saad and Kalakech (2009) using Johansen co-integration procedure and error correction model over the period 1962-2007 to investigate the effects of specific components of government expenditure on economic growth in Lebanon, found out that expenditure on education has a positive significant on economic growth in the long-run, whereas expenditure on defense show a negative relationship with economic growth. However, expenditures on health and agriculture were not significant in the long run. In the short run, the empirical results reveal negative relationships between educational and health spending, whereas agriculture and defense spending is found to be statistically insignificant. They concluded that education is the key sector to which public expenditure should be directed in order to foster economic growth in the long-run. Furthermore, Ali and Ahmad (2014) examined the impact of fiscal deficit and a disaggregated government expenditure on economic growth in Nigeria from 1970 to 2011 using autoregressive distributed lagged (ARDL) approach. Variables considered included GDP, budget deficit, capital and recurrent expenditures. The ARDL estimation reveals that a percentage increase in fiscal deficit expands the national output by $10.05 \%$ while a $10 \%$ increase in government capital expenditure in Nigeria increases the growth rate of the economy by $62.21 \%$. However, recurrent expenditure has no significant impact on economic growth. Adeboye (2008) used non-parametric methodology to study the long run relationship between budget deficit and economic growth incorporating saving and investment. He grouped 64 developing countries, Nigeria inclusive into three A, B, and C based on the level of their interest rate (countries with small deficit, moderate fiscal deficit and wide fiscal deficit respectively). He then computed economic ratio among which were gross savings-income and investment-income for the countries to enable him elicit the long run impact of their fiscal deficit on GDP. He came out with the conclusion that $70 \%$ of the long run impact of the fiscal deficit of the countries involved goes to investment as economic growth indicator. Thus fiscal deficit is an investment poison. Therefore, he established that interest rate volatility overtime could be traced to fiscal deficit as a source of distortion in growth model.

The work of Wosoweil (2013) examined the relationship between fiscal deficit and some macroeconomic aggregates in Nigeria for the period 1980-2010. He deployed the ordinary least square and Engel Granger cointegration approach in his work. The findings revealed a negative but insignificant relationship between fiscal deficit and gross domestic product. On the direction of causality, a bi-directional relationship was reported between fiscal deficit and GDP also between government tax and unemployment in Nigeria. However, Usman et al. (2011) using vector error correction model in their study of public expenditure and economic growth in Nigeria, differed significantly having reported presence of long-run relationship between government spending and economic growth. The work of Taiwo and Abayomi (2011) could be seen as a more specific analyses. Deploying ordinary least square on series from 1970-2008 to analyze government spending and economic growth in Nigeria, found a significant positive relationship between economic growth, capital and recurrent expenditures. Their analyses however contradicts the findings of Fajingbensi and Odusola (1999) who reported insignificant relationship between recurrent expenditure and economic growth. Omitogun and Tajudeen (2007) studied the contribution of fiscal policy in the achievement of economic growth in Nigeria, using the Solow growth model estimated with the use of ordinary least square method. The study found out that fiscal policy has not been effective in the area of promoting economic growth in Nigeria. Their findings revealed that factors such as policy inconsistency, level of corruption, wasteful spending, poor implementation and lack of feedback from implemented policies evident in Nigeria accounts for the ineffective fiscal policy in the country.

\section{METHODS OF STUDY}

\subsection{Research Design}

The study is mainly a quantitative research and adopted this design because it is an empirical study of the relationships and/or interactions between fiscal deficits; financing options vis-a-viz domestic and external borrowing and macroeconomic stability in Nigeria. The econometric modeling technique of Vector Autoregression (VAR) was adopted as the main analytical tool.

\subsection{Model Specification}

\subsubsection{The Variables in the Model.}

1). Economic Growth is defined here as the expansion in national output measured by growth in Gross Domestic Product (GDP). Economic growth is proxied by real GDP per Capita .We elected to use real GDP Per Capita in order to ascertain if increases in nominal GPD have been accompanied with improvements in social welfare, visa-viz declining poverty and income inequality among others. This is because GDP per Capita is a better measure of welfare and or improvements in general living standard of the population.

2). Domestic Credit to the Private Sector measures growth rate of bank credits to the private sector in Nigeria. This is an important component of the economy as it provides an indicator of the future productive capacity of the economy as well as capital formation. For economic growth and development to be achieved and sustained, private 
sector participation is imperative.

3). Fiscal Deficits defines the overall or accumulated shortfall of government revenues over government expenditures. Thus the overall gap between government expenditure and government revenue in a given period was used as fiscal deficits. The overall fiscal deficits figure which represents accumulated deficits or surpluses of the Federal Government of Nigeria overtime will be used for this variable. Overall fiscal deficits are chiefly financed by two broad classifications; Domestic and External Borrowings.

4). Domestic Borrowing Financed Deficit represents the size of overall fiscal deficit that is financed by domestic borrowing.

5). External Borrowing Financed Deficit represents the size of overall fiscal deficit that is financed by external borrowing

\subsubsection{Analytical Framework}

This study is aim at examining empirically the relationships between fiscal deficits; financing options vis-a-viz domestic and external borrowing and economic growth in Nigeria. This study adopted the Vector Autoregressive (VAR) model. The vector autoregressive (VAR) model is a theoretical modeling technique used in economic analysis. It is one of the most successful, flexible, and easy to use models for the analysis of multivariate time series. It is a natural extension of the univariate autoregressive model to dynamic multivariate time series. This study will adapt the model specified by (Sims 1980).

A VAR is system in which every equation has the same right hand variable, and those variables include lagged values of all of the endogenous variables. VARs are useful for forecasting systems of interrelated time series variables. VARs are also used for analyzing the dynamic impact of different types of random disturbances on systems of variables. The VAR approach sidesteps the need for structural modeling by treating every variable as endogenous variable in the system as a function of the lagged values of all the endogenous variables in the system.

The mathematical representation of a VAR is stated as follows:

$\mathrm{y}_{\mathrm{t}}=\mathrm{A}_{1} \mathrm{y}_{\mathrm{t}-1}+\mathrm{O}+\mathrm{A}_{\mathrm{p}} \mathrm{y}_{\mathrm{t}-1}+\mathrm{Bx}_{\mathrm{t}}+\mathrm{e}_{\mathrm{t}}$

Where $y_{t}$ is a $K$ vector of endogenous variables, $x_{t}$ is a $d$ vector of exogenous variables, $A_{1}, A_{p}$, and $B$ are matrices of coefficients to be estimated, and $e_{t}$ is a vector innovations that may be contemporaneously correlated but are uncorrelated with their own lagged values and uncorrelated with all of the right-hand side variables. Green (2000) and Gujarati (2009).

Since this study examines the relationships between fiscal deficits; financing options vis-a-viz domestic and external borrowing and economic growth as follows:

\section{Economic Growth Model}

This model is deployed to investigate the effects of overall fiscal deficits; domestic and external borrowing financed shocks on economic growth in Nigeria. The endogenous variables included in the model are specified thus:

(GDPP, OFDE, DBFD, EBFD, DCPS)

These variables can be transformed into a Vector Autoregressive (VAR) model with the variables stated in their lagged values.

The Vector Autoregressive (VAR) transformation of the economic growth model (equation 3.2) is stated as:

$\mathrm{GDPP}_{\mathrm{t}}=\alpha_{11} \mathrm{GDPP}_{\mathrm{t}-1}+\alpha_{12} \mathrm{OFDE}_{\mathrm{t}-1}+\alpha_{13} \mathrm{DBFD}_{\mathrm{t}-1}+\alpha_{14} \mathrm{EBFD}_{\mathrm{t}-1}+\alpha_{15} \mathrm{DCPS}_{\mathrm{t}-1}+\mathrm{e}_{1 \mathrm{t}}$

OFDE $_{\mathrm{t}}=\alpha_{21} \mathrm{GDPP}_{\mathrm{t}-1}+\alpha_{22} \mathrm{OFDE}_{\mathrm{t}-1}+\alpha_{23} \mathrm{DBFD}_{\mathrm{t}-1}+\alpha_{24} \mathrm{EBFD}_{\mathrm{t}-1}+\alpha_{25} \mathrm{DCPS}_{\mathrm{t}-1}+\mathrm{e}_{2 \mathrm{t}}$

DBFD $_{\mathrm{t}}=\alpha_{31} \mathrm{GDPP}_{\mathrm{t}-1}+\alpha_{32} \mathrm{OFDE}_{\mathrm{t}-1}+\alpha_{33} \mathrm{DBFD}_{\mathrm{t}-1}+\alpha_{34} \mathrm{EBFD}_{\mathrm{t}-1}+\alpha_{35} \mathrm{DCPS}_{\mathrm{t}-1}+\mathrm{e}_{3 \mathrm{t}}$

$\mathrm{EBFD}_{\mathrm{t}}=\alpha_{41} \mathrm{GDPP}_{\mathrm{t}-1}+\alpha_{42} \mathrm{OFDE}_{\mathrm{t}-1}+\alpha_{43} \mathrm{DBFD}_{\mathrm{t}-1}+\alpha_{44} \mathrm{EBFD}_{\mathrm{t}-1}+\alpha_{45} \mathrm{DCPS}_{\mathrm{t}-1}+\mathrm{e}_{4 \mathrm{t}}$

DCPS $_{\mathrm{t}}=\alpha_{51} \mathrm{GDPP}_{\mathrm{t}-1}+\alpha_{52} \mathrm{OFDE}_{\mathrm{t}-1}+\alpha_{53} \mathrm{DBFD}_{\mathrm{t}-1}+\alpha_{54} \mathrm{EBFD}_{\mathrm{t}-1}+\alpha_{55} \mathrm{DCPS}_{\mathrm{t}-1}+\mathrm{e}_{5 \mathrm{t}}$

Where;

GDPP $=$ Economic growth proxied by GDP Per Capita

OFDE $=$ Overall fiscal deficits

$\mathrm{DBFD}=$ Size of overall fiscal deficits financed by domestic borrowing

$\mathrm{EBFD}=$ Size of overall fiscal deficits financed by external borrowing

DCPS $=$ Growth rate of domestic credit to the private sector

\subsection{Data Required and Sources}

Time series data on GDP Per Capita, Federal Government overall fiscal deficit, domestic borrowing financed fiscal deficits, external borrowing financed deficits and domestic credit to the private sector between 1970 and 2016 was required for the estimation of the specified models. The data was sourced secondarily from the following:

1. CBN-Statistical Bulletin and Annual Reports and Statement of Accounts (various issues)

2. The International Monetary Funds (IMF).

\subsection{Data Analysis Technique}

This study relies on the descriptive statistics as well as Vector Autoregressive model (VAR) approach as the main 
analytical tools to analyze the determinants of foreign direct investment in Nigeria. In order to achieve this, the unit root model test, co-integration as well as Vector Autoregressive model (VAR) approaches were used to model the relationships between fiscal deficits; financing options vis-a-viz domestic and external borrowing and macroeconomic performance in Nigeria.

\subsubsection{Descriptive Statistics}

One of the methods researchers normally use to investigate the cause-effect relationship between variables is through descriptive statistics. Descriptive statistics is that type of statistics that involves organizing, summarizing and presenting data in a meaningful form or usable format. Thus, in this research simple averages (i.e. mean), kurtosis, Jarque-Bera, and more were employed to analyze the trends of the variables used in this study between 1970 and 2016.

\subsubsection{Unit Root Test}

It is now a common practice to examine the time series properties of economic data as a guide to a subsequent multivariate modeling and inference. If we discover that the variables are integrated of order greater than or equal to one, then it could be the case that these variables are co-integrated. Hence, the study employed the Augmented Dickey-fuller test (ADF) to test for the stationarity of the variables both at level and at difference. Thus, the model is stated as follows:

$\mathrm{y}_{\mathrm{t}}=\mu+\mathrm{P}_{\mathrm{yt}}-1+\varepsilon t$

Where ${ }^{\mu}$ and $\mathrm{P}$ are parameters and $\varepsilon t$ is assumed to be white noise, y is a stationary series.

If $-1<\mathrm{P}<\mathrm{I}$. if $\mathrm{P}=\mathrm{I}$, $\mathrm{y}$ is a non-stationary series.

If the process is started at some point, the variance of $y$ increases steadily with time and goes to infinity. If the absolute value of $\mathrm{P}$ is greater than one, the series is explosive. Therefore, the hypothesis of a stationarity series can be evaluated by testing whether the absolute value of $\mathrm{P}$ is strictly less than one. The simple unit root test described above is valid because the series is an AR (I) process. If the series is correlated at higher order lags, the assumption of white noise disturbances is violated.

The Dickey fuller tests take the unit root as the null hypothesis Ho: $\mathrm{P}=\mathrm{I}$. since explosive series do not make much economic sense, this null hypothesis is tested against the one-sided alternative $\mathrm{Hl}: \mathrm{P}<1$. The null hypothesis of a unit root is rejected against the one sided alternative if the t-statistic is less than the critical value.

\subsubsection{Co-integration Tests}

The co-integration deals with the methodology of modeling non-stationary time series variables. According to Maddala (1992) and Iyeli (2010) the theory of co-integration explains how to study the interrelationship between the long-run trends in economic variables. Basically, the idea of co-integration rests on the thesis that even though two time series may not themselves be stationary, a linear combination of the two non-stationary time series may be stationary. This study adopts the co-integration to test the existence of a long-term relationship among the variables in the five models.

\subsubsection{Vector Autoregressive (VAR)}

A VAR is system in which every equation has the same right hand variable, and those variables include lagged values of all of the endogenous variables. VARs are useful for forecasting systems of interrelated time series variables. VARs are also used for analyzing the dynamic impact of different types of random disturbances on systems of variables. The VAR approach sidesteps the need for structural modeling by treating every endogenous variable in the system as a function of the lagged values of all the endogenous variables in the system.

It has been pointed out in the literature that individual coefficients from the error-correction model are hard to interpret in the case of vector-autoregressive model. Consequently, the dynamic properties of the five models are analyzed by examining the impulse response functions and the variance decompositions.

\subsubsection{Impulse Response Function}

A shock to a particular variable may not only directly affect the variable but is also transmitted to all of the other endogenous variables. An impulse-response function traces the impact of a one-time shock to one of the innovations on the current and future values of the endogenous variables. The impulse-response, therefore, tells us how macro variables respond to innovations in foreign direct investment. In order words, an impulse-response will be applied to trace the reactions of the variables used in this study.

\subsubsection{Forecast Error Variance Decomposition (FEVD)}

While impulse-response functions trace the effects of a shock to one endogenous variable onto the other variables in the VAR, the Variance Decomposition provides information about the relative importance of each random innovation in affecting the random variables in the VAR (Hamilton, 1994). Therefore, Variance Decompositions show the magnitude of the variations in the endogenous variables. 


\subsection{RESULTS AND DISCUSSIONS}

\subsection{Data Analysis}

\subsubsection{Descriptive Statistics}

Tables 1 below presents the result of the descriptive statistics of the variables employed in the estimations in this study.

Table 1: Descriptive Statistics Results

\begin{tabular}{|l|l|l|l|l|l|}
\hline & GDPP & DCPS & OFDE & DBFD & EBFD \\
\hline Mean & 257884.8 & 2954173. & -245079.5 & 1605096. & 928822.9 \\
\hline Median & 247876.9 & 127117.7 & -15134.70 & 273836.4 & 451461.7 \\
\hline Maximum & 383023.4 & 21082717 & 202724.7 & 11058204 & 4890270. \\
\hline Minimum & 172402.7 & 351.5000 & -2208222. & 987.3000 & 175.0000 \\
\hline Std. Dev. & 64846.77 & 5739939. & 490515.4 & 2713923. & 1318736. \\
\hline Skewness & 0.451792 & 1.946550 & -2.284982 & 1.947913 & 1.613844 \\
\hline Kurtosis & 1.959329 & 5.425264 & 7.822578 & 5.875914 & 4.477524 \\
\hline Jarque-Bera & 3.719780 & 41.19968 & 86.44441 & 45.91966 & 24.67706 \\
\hline Probability & 0.155690 & 0.000000 & 0.000000 & 0.000000 & 0.000004 \\
\hline Sum & 12120587 & $1.39 \mathrm{E}+08$ & -11518735 & 75439504 & 43654677 \\
\hline Sum Sq. Dev. & $1.93 \mathrm{E}+11$ & $1.52 \mathrm{E}+15$ & $1.11 \mathrm{E}+13$ & $3.39 \mathrm{E}+14$ & $8.00 \mathrm{E}+13$ \\
\hline Observations & 47 & 47 & 47 & 47 & 47 \\
\hline
\end{tabular}

Source: Author's Computation (2017)

From tables 1, the standard deviation showed that DCPS (5739939.0) was the most volatile variable in the series followed by EBFD (2713923) and DBFD (1318736), while GDPP (64846.77) was the least volatile variable. The skewness statistic showed that GDPP, DCPS, DBFD and EBFD were positively skewed while OFDE variable was negatively skewed. The kurtosis statistic showed that GDPP was platykurtic, suggesting that its distributions were flat relative normal distribution while DCPS, OFDE, DBFD and EBFD was leptokurtic, suggesting that its distribution was peaked relative normal distribution. Based on these observations, it indicates that the series are non-stationary. However, this indication is not surprising since it involves time series data. In sum, there is unit root (non-stationarity) in the series. In such a case, the presence of unit root in the model is further supported by the values of the Jarque-Bera statistic of most of the variables (DCPS, OFDE, DBFD and EBFD) in tables 1 which are above 5.99 (that is, the Jarque-Bera statistic rejects the null hypothesis of normal distribution for all the variables at 5 percent critical value) depicting the presence of unit root.

Based on these observations it is therefore necessary to test for the long run relationship of the series. This we begin by testing for unit root of the series. The unit root test is conducted so as to make the variables stationary. The study adopts the Dickey and Fuller (1979) method called Augmented Dickey Fuller (ADF) unit root tests procedures.

\subsubsection{Unit Root Test}

Tables 2 and 3 below present the results of the stationarity test for each of the variables used in this study. The Augmented Dickey Fuller (ADF) test was tested with intercept but no trend.

Table 2: ADF Test Results at Level

\begin{tabular}{|l|l|l|l|l|}
\hline Variables & ADF test Statistic & ADF Critical Value & Level of Significance & Remark \\
\hline GDPP & 0.111445 & -2.926622 & $5 \%$ & Non Stationary \\
\hline DCPS & 4.565197 & -2.941145 & $5 \%$ & Non Stationary \\
\hline OFDE & 1.460327 & -2.926622 & $5 \%$ & Non Stationary \\
\hline DBFD & -6.268916 & -2.936942 & $5 \%$ & Stationary \\
\hline EBFD & -2.023845 & -2.928142 & $5 \%$ & Non Stationary \\
\hline
\end{tabular}

Source: Author's Computation (2017)

The results of the unit root test in table 2 reveals that DBFD variable is stationary at level while all the other variables were non stationary at level. We therefore accept the unit root null hypothesis indicating the presence of a unit root at levels and then proceed to employ first differentiation approach to establish the order of integration of the variables using the Augmented Dickey Fuller tests unit root test as presented in the table 3 below.

Table 3: ADF Test Results at $1^{\text {st }}$ Difference

\begin{tabular}{|l|l|l|l|l|l|}
\hline Variables & ADF test Statistic & ADF Critical Value & Level of Sign & Order of Integration & Remark \\
\hline GDPP & -5.956408 & -2.928142 & $5 \%$ & $\mathrm{I}(1)$ & Stationary \\
\hline DCPS & -8.464820 & -2.941145 & $5 \%$ & $\mathrm{I}(1)$ & Stationary \\
\hline OFDE & -5.965287 & -2.928142 & $5 \%$ & $\mathrm{I}(1)$ & Stationary \\
\hline EBFD & -3.860411 & -2.928142 & $5 \%$ & $\mathrm{I}(1)$ & Stationary \\
\hline
\end{tabular}

Source: Author's Computation (2017)

Tables 3 revealed that GDPP, DCPS, OFDE and EBFD were stationary in their first difference .Hence, the 
study then concluded that the variables of the model are integrated of order one. Having stabilized and stationarized the data, we now conduct the co-integration test.

\subsubsection{Co-integration Test Results}

Since all the variables were integrated of order 1, we turned to determine the existence of long run equilibrium relationship between the variables. Separate co-integration tests were carried out on fiscal deficits; financing options vis-a-viz domestic and external borrowing with respect to their relationship with Gross Domestic Product Per Capita (GDPP).

Non-stationary time-series can be co-integrated if there are linear combinations of them that are stationary, that is, the combination does not have a stochastic trend. In other words, if two or more I(1) variables are cointegrated, they must obey an equilibrium relationship in the long-run, although they may diverge substantially from that equilibrium in the short run.

The co-integration tests are based on the Johansen and Juselius (1989) test. Tables 4 present the co-integration test results.

Table 4: Co-integration Results for Economic Growth Model: GDPP, OFDE, DBFD, EBFD and DCPS Unrestricted Cointegration Rank Test (Trace)

\begin{tabular}{|lllll|}
\hline \hline $\begin{array}{l}\text { Hypothesized } \\
\text { No. of CE(s) }\end{array}$ & Eigenvalue & $\begin{array}{l}\text { Trace } \\
\text { Statistic }\end{array}$ & $\begin{array}{l}0.05 \\
\text { Critical Value }\end{array}$ & Prob.** \\
\hline \hline None * & 0.769188 & 164.2472 & 69.81889 & 0.0000 \\
At most 1 $*$ & 0.741666 & 98.27029 & 47.85613 & 0.0000 \\
At most 2 & 0.401951 & 37.36272 & 29.79707 & 0.0056 \\
At most 3 & 0.222073 & 14.22901 & 15.49471 & 0.0769 \\
At most 4 & 0.063006 & 2.928507 & 3.841466 & 0.0870 \\
\hline \hline
\end{tabular}

Trace test indicates 3 cointegrating eqn(s) at the 0.05 level

* denotes rejection of the hypothesis at the 0.05 level

**MacKinnon-Haug-Michelis (1999) p-values

Unrestricted Cointegration Rank Test (Maximum Eigenvalue)

\begin{tabular}{|lllll|}
\hline \hline $\begin{array}{l}\text { Hypothesized } \\
\text { No. of CE(s) }\end{array}$ & Eigenvalue & $\begin{array}{l}\text { Max-Eigen } \\
\text { Statistic }\end{array}$ & $\begin{array}{l}0.05 \\
\text { Critical Value }\end{array}$ & Prob.** \\
\hline \hline None * & 0.769188 & 65.97689 & 33.87687 & 0.0000 \\
At most 1 $*$ & 0.741666 & 60.90758 & 27.58434 & 0.0000 \\
At most 2 & 0.401951 & 23.13370 & 21.13162 & 0.0258 \\
At most 3 & 0.222073 & 11.30051 & 14.26460 & 0.1398 \\
At most 4 & 0.063006 & 2.928507 & 3.841466 & 0.0870 \\
\hline \hline
\end{tabular}

Max-eigenvalue test indicates 3 cointegrating eqn(s) at the 0.05 level

* denotes rejection of the hypothesis at the 0.05 level

**MacKinnon-Haug-Michelis (1999) p-values

Source: Author's Computation (2017)

The co-integration results in table 4 for growth model (GDPP, OFDE, DBFD, EBFD and DCPS) that both Trace test and Max-eigenvalue test indicates 3 co-integrating equation(s) at the 5 percent level of significance. This suggests that there is a long-run relationship between the variables. We therefore reject the null hypothesis of no co-integration amongst the variables but we do not reject the alternative hypothesis.

\subsubsection{VAR Lag Order Selection}

The first step in model building, impulse response analysis and decomposition of the forecast error variance is the selection of the lag order. In this study we use some commonly used lag-order selection criteria to choose the lag order, such as the "Akaike information criterion (AIC)", "Schwartz criterion (SC)", "Hannam-Quinn criterion (HQC)" and "final prediction error (FPE)" to determine the optimum lag and then analyze the residuals.

Table 5: Optimum Lag Test

\begin{tabular}{|l|l|}
\hline AIC & 2 \\
\hline SC & 2 \\
\hline HQC & 2 \\
\hline FPE & 2 \\
\hline
\end{tabular}

Source: Author's Computation (2017) 
Table 5 shows that lag 2 is chosen as the optimum lag in the specification of VAR model on the relationship between fiscal deficit and economic growth in Nigeria between 1970 and 2016. Thus, we now estimate and analyze the VAR, impulse response and decomposition of the forecast error variance.

\subsubsection{Impulse Response Analysis and Variance Decomposition}

Since the long-run relationship has been established amongst the variables in the five models, their dynamic properties are further supplemented by the impulse response analysis and forecast error variance decomposition. The first difference of the series can be estimated by inverting the VAR into a moving average representation after which the impulse response as well as the variance decomposition can be estimated.

\subsection{5a Impulse Response Function (IRF) Analysis}

The impulse response analysis is presented in tables 6 below. It presents a fraction of the impulse response analysis for each variable in the five models that is attributed to its own innovations and to innovations in other variables.

Table 6: Impulse Response Function for Growth Model: GDPP $=\mathbf{f}($ OFDE, DBFD, EBFD, DCPS)

\begin{tabular}{|l|l|l|l|l|l|}
\hline Period & GDPP & OFDE & DBFD & EBFD & DCPS \\
\hline 1 & 16211.87 & 0.000000 & 0.000000 & 0.000000 & 0.000000 \\
\hline 2 & 16324.05 & 2661.930 & 1902.350 & 1513.199 & 3120.845 \\
\hline 3 & 15556.03 & -1355.522 & 1979.360 & 3622.419 & 1403.571 \\
\hline 4 & 14763.23 & -4424.224 & 4044.835 & 6396.936 & 999.7679 \\
\hline 5 & 13181.64 & -5376.131 & 3791.870 & 7496.810 & 1347.979 \\
\hline 6 & 12176.11 & -6442.095 & 4443.540 & 9326.610 & 1815.645 \\
\hline 7 & 10556.70 & -7952.655 & 5400.586 & 10111.34 & 1753.380 \\
\hline 8 & 8773.334 & -9405.878 & 5957.982 & 9429.626 & 1752.127 \\
\hline 9 & 7327.150 & -10215.61 & 5968.961 & 8043.016 & 2336.407 \\
\hline 10 & 6315.371 & -10777.03 & 6056.549 & 6766.963 & 3181.807 \\
\hline
\end{tabular}

Source: Author's Computation (2017)

Table 6 presents the impulse response function of GDP per capita (GDPP) in model one. It shows that the response of GDP per capita (GDPP) to one standard innovation in Overall Fiscal Deficit (OFDE) is all negative at each time responsive period except in the $2^{\text {nd }}$ period. This implies that OFDE on the average has a negatively bullish relationship with GDPP in the long-run as shown in figure 1 below.

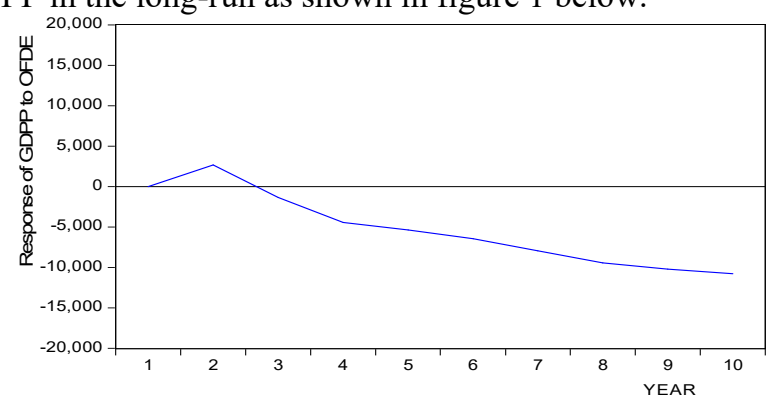

Figure 1: Response of GDPP to OFDE

Table 6 also reveals that the response of GDP per capita (GDPP) to one standard innovation in the size of overall fiscal deficit financed by domestic borrowing (DBFD) is all positive at each time responsive period in the long-run, implying that DBFD has positive relationship with GDPP in the long-run as shown in figure 2 below.

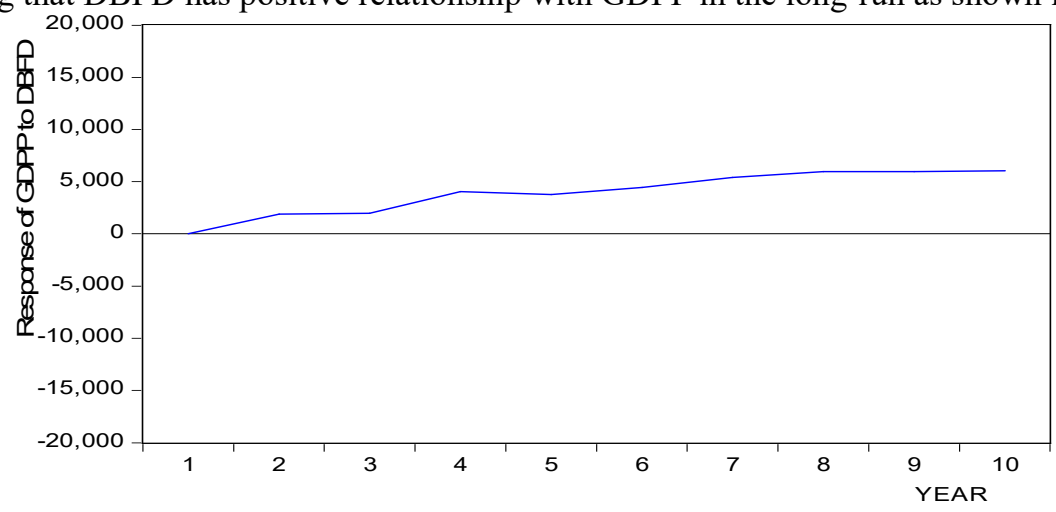

Figure 2: Response of GDPP to DBFD

Table 6 also reveals that the response of GDP per capita (GDPP) to one standard innovation in the size of overall fiscal deficit financed by external borrowing (EBFD) is all positive at each time responsive period in the long-run, implying that EBFD has positive relationship with GDPP in the long-run as shown in figure 3 below. 


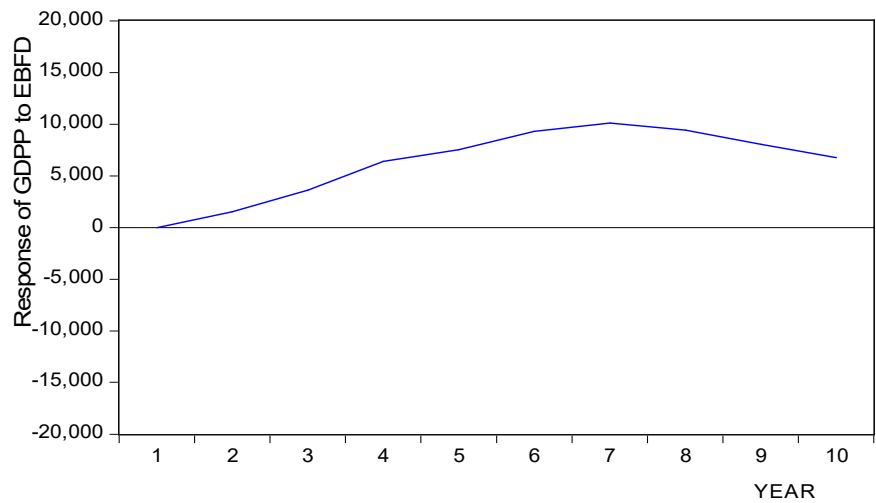

Figure 3: Response of GDPP to EBFD

Table 6 also reveals that the response of GDP per capita (GDPP) to one standard innovation in Domestic Private Sector Credit (DCPS) is all positive at each time responsive period in the long-run, implying that DCPS has positive relationship with GDPP in the long-run as shown in figure 4 below.

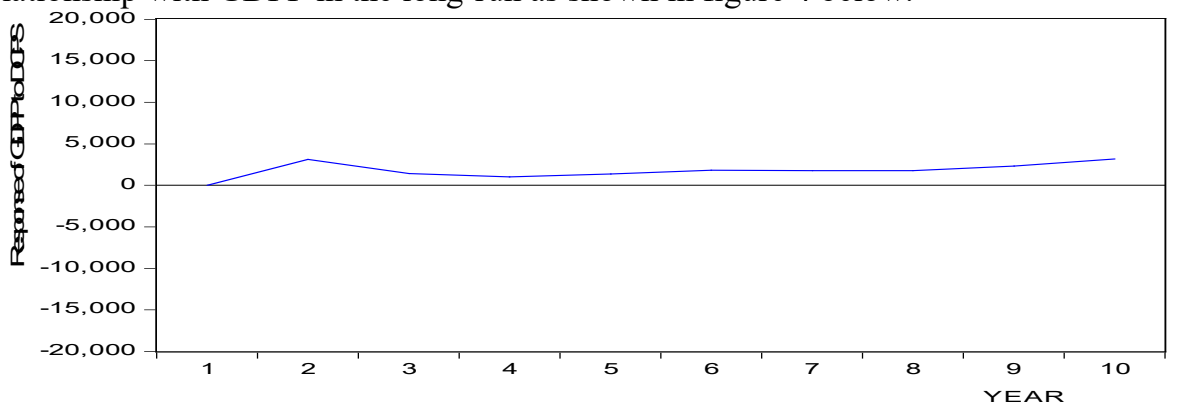

Figure 4: Response of GDPP to DCPS

\subsection{5b Forecast Error Variance Decomposition (FEVD) Analysis}

The forecast error variance decomposition analysis is presented in tables 7 below. It presents a fraction of the forecast error variance decomposition for each variable in the five models that is attributed to its own innovations and to innovations in other variables. The variance decomposition was estimated so as to see the forecast error components of each of the variables originating from shocks in the system. The ordering of the variables in the variance decomposition is vital and this is stated in tables 7 below over the same forecasting horizon for a period of ten (10) years.

Table 7: Forecast Error Variance Decomposition for Growth Model: GDPP $=\mathbf{f ( O F D E , ~ D B F D , ~ E B F D , ~}$ DCPS)

\begin{tabular}{|l|l|l|l|l|l|l|}
\hline Period & S.E. & GDPP & OFDE & DBFD & EBFD & DCPS \\
\hline 1 & 16211.87 & 100.0000 & 0.000000 & 0.000000 & 0.000000 & 0.000000 \\
\hline 2 & 23495.39 & 95.88173 & 1.283594 & 0.655565 & 0.414788 & 1.764326 \\
\hline 3 & 28545.95 & 94.65173 & 1.095058 & 0.924908 & 1.891304 & 1.436998 \\
\hline 4 & 33326.85 & 89.06648 & 2.565735 & 2.151612 & 5.071898 & 1.144275 \\
\hline 5 & 37225.46 & 83.92647 & 4.142196 & 2.762129 & 8.120937 & 1.048272 \\
\hline 6 & 41055.09 & 77.79532 & 5.867651 & 3.442309 & 11.83731 & 1.057408 \\
\hline 7 & 44661.94 & 71.32440 & 8.128846 & 4.370965 & 15.12815 & 1.047641 \\
\hline 8 & 47829.03 & 65.55607 & 10.95532 & 5.362994 & 17.07792 & 1.047690 \\
\hline 9 & 50511.77 & 60.88165 & 13.91271 & 6.204859 & 17.84747 & 1.153307 \\
\hline 10 & 52915.64 & 56.90018 & 16.82529 & 6.963945 & 17.89813 & 1.412461 \\
\hline
\end{tabular}

Source: Author's Computation (2017)

Table 7 (GDPP model) present the results of the variance decomposition for model one. It shows that 100 percent of variance in GDP per Capita (GDPP) in period 1 is explained by the shock from the variable itself. This implies that there was no shock from other variables. In period 2, 95 percent of the variance in GDP per Capita (GDPP) was explained by the shock from the variable itself; 1.28 percent from fiscal deficit (OFDE); 0.65 percent from the size of fiscal deficit financed by domestic borrowing (DBFD); 0.41 percent from the size of fiscal deficit financed by external borrowing (EBFD); and 1.76 percent from Domestic private Sector Credit (DCPS).

Inferences from period 2 to 10 shows that apart from the variance due to the shock from the variance of GDP per Capita (GDPP) itself, the size of fiscal deficit financed by external borrowing (EBFD) is the variable with the highest percentage of induced variance on GDP per Capita of about 17 percent in period 10 while OFDE, DBFD and DCPS induce 16 percent, 6 percent and 1 percent respectively. 


\subsubsection{VAR Granger Causality Results}

The results of the VAR granger causality tests of the variables in the five models are presented in Tables 8 below. Table 8: VAR Granger Causality Tests Result for Growth Model: GDPP, OFDE, DBFD, EBFD, DCPS

\begin{tabular}{|l|l|l|l|l|l|l|}
\hline \multirow{3}{*}{$\begin{array}{l}\text { Dependent } \\
\text { Variables }\end{array}$} & GDPP & OFDE & DBFD & EBFD & DCPS & $\begin{array}{l}\text { Joint } \\
\text { Causality }\end{array}$ \\
\cline { 2 - 6 } GDPP & - & 2.6792 & 1.4811 & 5.9964 & 2.3061 & 12.4268 \\
& & {$[0.2619]$} & {$[0.4769]$} & {$[0.0499]$} & {$[0.3157]$} & {$[0.1332]$} \\
\hline OFDE & 0.7297 & - & 1.9888 & 0.4333 & 10.8868 & 43.9785 \\
& {$[0.6943]$} & & {$[0.3699]$} & {$[0.8052]$} & {$[0.0043]$} & {$[0.0000]$} \\
\hline DBFD & 1.1495 & 12.2778 & - & 49.4235 & 8.7898 & 80.8034 \\
& {$[0.5628]$} & {$[0.0022]$} & & {$[0.0000]$} & {$[0.0123]$} & {$[0.0000]$} \\
\hline EBFD & 5.6037 & 0.0560 & 2.0926 & - & 0.2592 & 12.5578 \\
& {$[0.0607]$} & {$[0.9724]$} & {$[0.3512]$} & & {$[0.8784]$} & {$[0.1280]$} \\
\hline DCPS & 3.2552 & 6.2809 & 56.3775 & 11.4720 & - & 62.5239 \\
& {$[0.1964]$} & {$[0.0433]$} & {$[0.0000]$} & {$[0.0032]$} & & {$[0.0000]$} \\
\hline
\end{tabular}

Note: The figures in parenthesis are the probability values

Source: Author's Computation (2017)

Table 8 above present the VAR granger causality tests result for model one that is economic growth model. From the result, we found that there is no joint granger causality running from OFDE, DBFD, EBFD and DCPS to GDPP. This implies that OFDE, DBFD, EBFD and DCPS jointly do not have a significant causality relationship with GDPP.

The study also reveals that there is a joint granger causality running from GDPP, DBFD, EBFD and DCPS to OFDE and also there is a joint granger causality running from GDPP, OFDE, EBFD and DCPS to DBFD. Again, the study also reveals that there is no joint granger causality running from GDPP, OFDE, DBFD, and DCPS to EBFD while there is a joint granger causality running from GDPP, OFDE, DBFD, and EBFD to DCPS.

\subsection{Discussion of Findings}

The empirical result from the variance decomposition analysis shows that the percentage of variance explained by own shocks for GDP per capita (GDPP) declines to about 96 percent in the second period and continues falling until it ends with an average of about 57 percent in the $10^{\text {th }}$ period.

The study further reveals that inferences from periods 2 to 10 shows that the percentage variance in GDPP due to shocks from overall fiscal deficits (OFDE) decreased from 1.28 percent in period 2 to 1.09 percent in period 3 and later increased at a constant rate from 2.56 percent in period 4 to an average of about 17 percent in period 10. Also, the percentage variance in GDPP due to shocks from the size of fiscal deficits financed by both domestic and external borrowing maintained a constant rate of increase from the $2^{\text {nd }}$ period to the $10^{\text {th }}$ period. That is, it increased from steadily from 0.65 percent and 0.41 percent respectively in period 2 to an average of about 7 percent and 18 percent respectively in period 10. Again, the percentage variance in GDPP due to shocks from domestic credit to the private sector (DCPS) decreased steadily from 1.76 percent in period 2 to 1.04 percent in period 5 and later increase at a constant rate until the $10^{\text {th }}$ period with an average of about 1.41 percent.

In sum, the study reveals that among the endogenous variables, the shocks due to the size of fiscal deficits financed by external borrowing (EBFD) contributes more to variance in GDP per capita (GDPP) with an average of about 18 percent followed by overall fiscal deficits (OFDE) with an average of about 17 percent with the period under review. This implies that although fiscal deficit was found to cause significant variation in economic growth, the size of fiscal deficits financed by external borrowing (EBFD) is the main shocks causing the variation in economic growth as proxied by GDP per capita (GDPP) in Nigeria within the period of study. Our finding corroborates with Keynes (1936) and other previous studies such as Egbetunde (2012) and Atique and Malik (2012).

\section{SUMMARY, CONCLUSIONS and RECOMMENDATIONS}

The study investigates empirically the relationships between fiscal deficits; financing options vis-a-viz domestic and external borrowing and economic growth in Nigeria between 1970 and 2016. The major analytical tools employed for the analysis of data for the study were descriptive statistics, co-integration and vector auto regression (VAR) estimation methods. The data for the empirical analysis was sourced from secondary sources such as the CBN statistical bulletin and the International Monetary Fund. The study used GDP per capita (GDPP) to proxy economic growth whereas Overall Fiscal Deficits (OFDE), fiscal deficit financed by Domestic Borrowing (DBFD), fiscal deficit financed by External Borrowing (EBFD), and Domestic Credit to the Private Sector (DCPS) were used as the endogenous variables. The results of the variance decomposition reveal that overall fiscal deficits 
(OFDE) and especially the size of fiscal deficits financed by external borrowing (EBFD) are the main shocks causing the variation in GDP per capita (proxy of economic growth). The study concludes that fiscal deficits have significant positive impact on economic growth. Thus, fiscal deficits especially when financed chiefly by external borrowing are capable of stimulating economic growth in Nigeria. However, overall fiscal deficits (OFDE) financed by domestic borrowing (DBFD) is found to be significantly ineffectual in stimulating economic growth in Nigeria. These findings may be linked to the high cost of domestic borrowing which is characterized by high interest rate and shorter tenors compare to external borrowing sources. Morse so, fiscal deficits have been chiefly financed through domestic borrowing in recent history which significantly affects domestic credit to the private sector negatively, as well as increases in Nigeria's debt service burden to an unsustainable pinnacle.

The study, therefore, recommends Nigeria's fiscal deficits as there may be unplanned negative macroeconomic effects of unrestricted fiscal deficits like inflationary pressures and increase in interest rate. These undesirables when triggered by unrestricted deficits, their negative consequences would far outweigh any gain these deficits could produce in terms of output expansion. Secondly, government should adopt fiscal adjustment mechanism that increases revenue through improved taxes rather than borrowing to finance deficit and dependence on crude oil. With appropriate adjustments and reforms in place, Nigeria has enormous capacity to increase revenue from taxes to finance her fiscal expenditures. Nigeria's tax to GDP ratio that is currently at about 6 percent indicates huge underutilized capacity to generate revenue through taxes. Finally, high volume of domestic borrowing should be discouraged as this affects negatively private sector investment and consequently compounds unemployment issues since the government naturally cannot compete with the private sector. Fiscal managers should rather elect to finance fiscal deficits mainly through the issuance of bonds and increases in tax revenues. The present utilization of approximately 25 percent of the annual budget for debt servicing is anti-development and unsustainable. If borrowing is inevitable, external borrowing financing sources should be the preferred choice. This financing option is cheaper in terms of interest services and longer tenors, as well as has much magnitude effect in stimulating output growth positive compare to domestic borrowing sources.

\section{References}

Abiola, A. G and T. Folorunso (2000). The long run determinants of inflation in Nigeria. The Nigerian Journal of Economics and Social Studies Vol.42, No.1

Adeboye, O. (2008). Impact of Fiscal Reform on Foreign Trade. Ibadan: Stat-Pub.

Ali, D.U and U. G Ahmad (2014). Effect of Fiscal Deficit and Government Expenditure on Economic Growth in Nigeria. JORIND 12 (1); www.transcampus.org/journals

Anyanwu, J.C. (1993). Monetary Economics: Theory, Policy and Institutions. Onitsha: Hybrid Publishers LTD Anyanwu, J. C. (1998). Do Fiscal Deficits Produce High Interest Rates? The Case of Nigeria, Ghana and the Gambia. CBN Economic and Financial Review, Vol. 36, No. 1,

Asogwa, F.O and I. C Okeke (2013). The Crowding Out Effect of Budget Deficits on Private Investment in Nigeria. European Journal of Business and Management ISSN 2222-1905 (Paper) ISSN 2222-2839 (Online) Vol.5, No.20, 2013; Retrieved from www.iiste.org

Atique, R., \& Malik, K. (2012). Impact of domestic and external debt on the economic growth of Pakistan. World Applied Sciences Journal, 20 (1), 120-129.

Central Bank of Nigeria. Annual Report and Statement of Account: Various Issues; Abuja Nigeria

Central Bank of Nigeria (2009). Statistical Bulletin: Central Bank of Nigeria. Abuja.

Central Bank of Nigeria (2015). Statistical Bulletin: Central Bank of Nigeria. Abuja

Cooper, J.P and Fisher, S (1997). Stabilization policy and lags. Journal of Political Economy Vol.3 No.1

Debt Management Office (2010). Federal Government domestic debt outstanding by instruments; June, Abuja Nigeria

Debt Management Office (2017). Federal Government Public debt outstanding; December, 2016, Abuja Nigeria

Dewett, K.K. (2009). Modern economics theory (Revise edition). New Delli S. Chand \& Company Ltd.

Egbetunde, T. (2012). Public debt and economic growth in Nigeria: Evidence from Granger Causality. American Journal of Economics, 2(6), 101-106. DOI: 10.5923/j.economics.20120206.02

Fajingbesi, A. A \& Odusola, A.F (1999). Public expenditure and growth. A Paper Presented at a Training Programme on Fiscal Policy planning Management in Nigeria, organized by NCEMA, Ibadan. 137-179

Fan, S, P. and S. Thoret (2008). Linkage between Government Spending, growth and Poverty in rural India. Research Report 110 (Washington: International Food Policy Research Institute).

Friedman, B. M. (1975). Rational Expectations are policy adaptation. Harvard Discussion papers.

Friedman, B. M. (1978). Crowding out or crowding in? Economic consequences of financing government deficits. Brookings Papers on Economic Activity: 593-641.

Gale, W. G. and O. Peter (2003). Economic Effects of Sustained Budget Deficits. National Tax Journal Vol. 56 No. 3, 2003, pp. 463-485

Greene, W. H (2000). Econometric Analysis. Fourth edition. New York: Prentice Hall 
Gujarati D.N and Porter D.W (2009). Basic econometrics: New York, McGraw-Hill/Irwin International edition International Monetary Funds (2017). World Economic Outlook: Washington D.C

Jhinghan M.L (1997). Macro-economic theory: Vihar, Vrinda Publications (P) ltd, 10th revised and enlarged edition.

Jhinghan M.L (2002). The economics of development and planning: Vihar, Vrinda Publications (P) ltd 35th revised and enlarged edition.

Johansen, S. (1995). Likelihood-based Inference in Co-integrated Vector Autoregressive Models. Oxford, Oxford University Press.

Kennedy .P. (1998). A Guide to Econometrics. Fourth edition. Cambridge: The MIT Press.

Keynes, J.M. (1936). The General Theory of Employment, Interest Rate and Money: London: Macmillian.

Majumder, A., (2007). Does Public Borrowing Crowd-out Private Investment? The Bangladesh Evidence. Bangladesh Bank Working Paper, WP 0708.

Mohanty R. K (2012). Fiscal deficit-economic growth nexus in India: A Co-integration analysis. Centre for Economic Studies \& Planning, School of Social Sciences, Jawaharlal Nehru University; New Delhi- 110067

National Bureau of Statistics (2012). Annual Abstract of Statistics. Abuja Nigeria: NBS Press

Obi B. and A. Nurudeen (2008). Do fiscal deficits raise interest rates in Nigeria? A vector autoregression approach. Journal of Applied Quantitative Methods, Vol.4 No.3 Fall 2008

Oluba, M.N. (2008). How years of fiscal deficits emasculated the Nigerian economy. Economic Reflections, 1(5): 6-10.

Omitogun O. and Tajudeen A. (2007). Fiscal Policy and Nigerian economic growth. Journal of Research in national development Vol.5: 22-26

Onwioduokit, E. (2005). Fiscal Deficit, Inflation and Output Growth in Nigeria: A Vector Error Correction Model Approach; Journal of Economic and Financial Studies, Vol. 2 No. 1

Philips, A. (1986). Understanding Spurious Regression. Journal of Econometrics 33:165-193

Saad A. and Kalakech L., (2009). Public expenditure and economic growth in Lebanon. Middle Eastern Finance and Economics-Issue 4

Sims, C. (1980). Macroeconomics and reality. Econometrica, 48(1): 1-48

Udaba, S.I (2002). Introduction to Nigerian Public Finance. Enugu. Linco Press Nig. Ltd

Uduakobong, I. (2014). Budget Deficit and Inflation in Nigeria: An Empirical Analysis (1970-2010).Journal of Economics and Sustainable Development ISSN 2222-1700 (Paper) ISSN 2222-2855 (Online) Vol.5, No.2, 2014; Retrieved from www.iiste.org

World Bank (1996). Nigeria Federal Public Expenditure review, report No. 1447. The World Bank Washington D.C.

Wosowei E. (2013). Fiscal deficits and macroeconomic aggregates in Nigeria. Kuwait Chapter of Arabian Journal of Business and Management Review. Vol. 2, No.9; May, 2013 